\title{
DIFFERENCES IN ENVIRONMENTAL GOVERNANCE LEVELS IN THE SUSTAINABLE DEVELOPMENT OF RURAL AREAS OF THE WIELKOPOLSKIE VOIVODESHIP*
}

\author{
Małgorzata Dolata, Magdalena Jaworska ${ }^{\varpi}$ \\ Poznań University of Life Sciences, Poland
}

\begin{abstract}
The purpose of this paper is to assess the level and spatial differentiation of selected environmental governance parameters in the context of implementing the sustainable development concept in rural areas of the Wielkopolskie voivodeship districts in 2005 and 2015 . The research procedure was made up of three steps: review of the relevant literature and selection of indicators to describe the environmental governance topics; analyzing the changes in, and spatial differentiation of, specific environmental governance components; and ranking the districts. The basic source of data was the online database delivered by the Central Statistical Office in Warsaw, the Local Data Bank. As shown by the results, there is considerable spatial differentiation of specific environmental governance components; however, when analyzed globally, environmental governance proves to be a relatively non-diversified process. In 2015, the highest sustainability levels were recorded in rural areas of the following districts: Złotów, Kępno and Jarocin. In turn, the lowest levels were found in Września, Wągrowiec and Śrem districts.
\end{abstract}

Keywords: sustainable development, environmental domain, rural area, Wielkopolskie voivodeship

\section{INTRODUCTION}

In highly developed economies, the destruction of the natural environment caused by rapid economic development became a topic of interest in the late 1960s and beginning of the 1970s. At that time, it became noticeable that the secondary effects of economic activity which mean extracting, processing, moving and consuming natural resources, result not only in a faster degradation of the natural environment but also in the impoverishment of the population. Therefore, placing an important focus on the environmental aspect became an alternative to the traditionally defined development oriented on a resource-intensive, inefficient, structurally unsustainable production growth accompanied by environmental degradation. Sustainable development, the new socioeconomic development concept, takes into consideration the multilateral economic development while giving priority to environmental protection (Leśniewski, 2010; Żylicz, 2004). Therefore, it is a compromise between environmental, economic and social goals (Hadryjańska, 2015; Stanny, 2013).

*The publication was financed by the Department of Economics, Poznań University of Life Sciences.

$凶$ PhD Małgorzata Dolata, Department of Economics, Poznań University of Life Sciences, Wojska Polskiego 28 St., 60-637

Poznań, Poland, e-mail: dolata@up.poznan.pl 
The sustainable development concept takes on particular significance in respect to rural areas which represent over $93 \%$ of the Polish national territory and cumulate many valuable natural public goods while providing important environmental functions to the entire country. Also, by taking into consideration the key roles of the natural environment for strategic development goals, the sustainable development concept is of particular importance for the activity types whose outcomes depend on natural conditions (Adamowicz, 2000). The concept of sustainable development of rural areas includes activities aimed at improving the conditions of economic activity and living standards for the rural population while not harming specific rural resources which include natural values, rural landscape, traditions and cultural heritage (Dolata, 2015; Roszkowska-Mądra, 2009). It is also important to ensure an even spatial distribution of this process.

\section{PURPOSE, MATERIALS AND METHODOLOGY OF STUDIES}

The purpose of this paper is to assess the level and spatial differentiation of selected environmental governance parameters in the context of implementing the sustainable development concept in rural areas of the Wielkopolskie voivodeship districts in 2005 and 2015.

This was done with an ex-post empirical analysis $(2005,2015)$ of environmental governance indicators based on selected statistical methods (structural and dynamic indicators, measures of position). The basic source of data was the online database delivered by the Central Statistical Office in Warsaw, the Local Data Bank (n.d.). This study covered the rural areas of the Wielkopolskie voivodeship (the total area of rural municipalities and rural areas extracted from the urbanrural municipalities).

The research procedure was made up of three steps. First, based on the relevant literature, a review was conducted of indicators that describe the environmental governance fields. Based on substantive and statistical grounds, five of them were selected, including two with a stimulating effect: forest cover (\% of forests in the total area) and the share (percent) of population served by sewage treatment plants in the total population; and three with an inhibiting effect: water consumption $\left(\mathrm{m}^{3} /\right.$ person), mixed waste ( $\mathrm{kg} /$ person) and electric power consumption (kWh/person). The second stage was the analysis of changes to, and spatial differentiation of, specific environmental governance components. The final third step consisted in ranking the districts. For that purpose, the districts were arranged by each of the indicators covered by this study. Then, a score ranging from 1 to 31 was assigned to each of them. It was assumed that the highest score corresponds to the most favorable option, i.e. the lowest values of variables with an inhibiting effect and the highest values of variables with a stimulating effect.

\section{SUSTAINABLE DEVELOPMENT MEASURES}

As the sustainable development concept changed over time, increased attention was paid to the related indicators. In the relevant literature, propositions were put forward for the quantification of sustainable development as regards both the spatial dimension (at various territorial levels: global, national, regional, sub-regional and local level) and the temporal dimension. Sustainable development indicators represent a kind of information and diagnostic tools. As indicators of measurable effects of implementing the sustainable development concept, they support putting that concept into operational use to control the attainment of goals set in strategic documents of a territorial unit. Also, they play the role of a basic monitoring tool (Borys, 2005; Stanny and Czarnecki, 2011).

In Poland, the studies on the construction of sustainable development indicators were initiated in the 1990s (Borys and Fiedor, 2008). In turn, in the 2000s, efforts were made to develop unified indicators of sustainable development at various levels of the country's territorial division (NUTS). This resulted in developing a series of indicators grouped in accordance with the integrated governance principle (Stanny and Czarnecki, 2011) as a part of the public statistics system (the Local Data Bank of the Central Statistical Office).

The structural basis for the development of integrated governance is composed of seven strategic goals. The attainment of these goals within specific timeframes is recorded with the use of sustainable development indicators. Currently, the indicators are grouped by four governance fields: social governance, economic governance, environmental governance, and institutional and political governance. Each of the governance types is applicable to specific areas with associated indicators 
(Local Data Bank, n.d.). This is consistent with the concept developed by the EU who proposed a set of sustainable development indicators composed of ten thematic areas (spanning from economic, social and environmental aspects through to institutional and global partnership matters). The above areas are divided into sub-topics representing specific operational goals and measures taken under the Sustainable Development Strategy. The current set is made up of over 130 indicators, including 10 considered to be main indicators (Sustainable..., 2015).

According to the sustainable development concept, a strict relationship exists between environmental governance and natural capital together with its sustainability principle. If effectively implemented, environmental governance will allow to preserve the condition of natural heritage and deliver it to future generations as a capital that ensures good quality of living. In accordance with the classification used by the Central Statistical Office, environmental governance includes the following thematic areas: climate change (3 indicators), energy (4 indicators), air protection (4 indicators), marine ecosystems ( 1 indicator), fresh water resources (3 indicators), land use (3 indicators), biodiversity ( 2 indicators), waste management (4 indicators). As regards rural areas, the measurement of the effects of implementing sustainable development concepts is extremely difficult at the level of municipalities (NTS5). This is because the Local Data Bank does not store any local statistical data necessary for the construction of many indicators covered by environmental and other types of governance.

\section{RESULTS OF THE STUDY}

In the Wielkopolskie voivodeship, the distribution of forests is quite uneven (Program..., 2012). In 2015, the forest cover ratio was $25.7 \%$, reaching a higher level $(26.3 \%)$ in rural areas. The largest share of forests in rural areas was recorded in the following districts: Czarnków-Trzcianka (51.8\%), Złotów (46.4\%), Międzychód (45.3\%) and Nowy Tomyśl (38.8\%).

Increasing the share of forests in the country's total area is among the objectives of the government's forest policy. The forest cover ratio allows to monitor the attainment of the first objective of the "Energy Security and Environmental Policy" which is the sustainable management of environmental resources. It is assumed that the forest cover ratio will reach $30.0 \%$ in 2020
(Kierunki..., 2010). As shown by the analysis of the forest cover ratio for the Wielkopolskie voivodeship, while the developments are positive and consistent with the expectations, the pace of changes in the years covered by the analysis was relatively slow (Table 1). Compared to 2005 , the forest cover in rural areas has grown by as little as 0.29 percentage points (and by 0.71 percentage points on a countrywide basis). These results were mainly affected by the larger share of forests in the following districts: Złotów (by 1.19 percentage points), Pleszew (by 0.64 percentage points), Koło (by 0.56 percentage points) and Konin (by 0.50 percentage points). Meanwhile, a decline in the forest cover ratio was reported in the following districts: Chodzież (by 0.13 percentage points), Gostyń (by 0.09 percentage points) and Rawicz (by 0.04 percentage points).

Sustainable development also involves appropriate management of water resources. In 2015, per capita water consumption by the national economy and population was $261.7 \mathrm{~m}^{3}$, which means a reduction by $3.82 \%$ compared to 2005. In the Wielkopolskie voivodeship, that indicator reached $433.2 \mathrm{~m}^{3}$, one of the country's highest levels, despite a reduction by $27.4 \%$ from 2005 . The evolution follows the desired direction which results from such factors as increased investments in water management. The opposite trend was observed in rural areas, both in Poland and in the voivodeship. This could be explained mainly by the increasing demand from the industry and by the irrigation of agricultural land and forests. Also, in rural areas of Wielkopolskie voivodeship, the exploitation rate of aquatic resources was three times lower than the countrywide level. In 2005-2015, the per-capita water consumption ratio in the voivodeship increased by $3.2 \%\left(3.31 \mathrm{~m}^{3}\right.$ per capita), reaching $107.3 \mathrm{~m}^{3}$ per capita (Table 1). As shown by the spatial dispersion analysis, that ratio largely differs across regions. In 2015, extremely high water consumption levels were reported in the following districts: Chodzież $\left(528.1 \mathrm{~m}^{3}\right.$ per capita), Wagrowiec $\left(324.7 \mathrm{~m}^{3}\right.$ per capita), Międzychód (298 $\mathrm{m}^{3}$ per capita) and Ostrzeszów (239.5 $\mathrm{m}^{3}$ per capita). Worryingly, five districts exceeded the average growth rate of the indicator calculated for Polish rural areas in the period covered by this study (27.4\%), including the Czarnków-Trzcianka, Oborniki and Chodzież districts. Meanwhile, note that twelve districts recorded a decrease in water consumption, and the highest reduction rate (by $117.6 \mathrm{~m}^{3}$ ) was observed in the Wągrowiec district. In 2015, the most 
economic exploitation and management of aquatic resources (not in excess of $60 \mathrm{~m}^{3}$ per capita) was recorded in the following districts: Kępno, Koło, Konin, Pleszew and Słupca.

In addition to effective water management, sustainable development also requires the aquatic resources to be protected against pollution which mainly originates from wastewater. In 2015, in the Wielkopolskie voivodeship, $44.3 \%$ of the rural population were served by sewage treatment plants (compared to $39.6 \%$ on a countrywide basis). In the period under consideration, the number of rural users of appropriate, safe water treatment systems (sewage, home wastewater treatment plants etc.) more than doubled. Undoubtedly, this results from the development of municipal systems for wastewater collection and treatment. In addition to new treatment plants put into service, the water supply and sewerage networks were extended; obsolete and inefficient facilities were decommissioned; treatment plants were upgraded; investments were made in equipment enabling the reduction of pollutant load in wastewater; there was an increase in the number of biological wastewater treatment plants and of treatment plants with improved nutrient removal processes.

In the Wielkopolskie voivodeship, the spatial distribution of the indicator of the population share served by wastewater treatment plants was quite even. In 2015, the highest share was recorded in the Chodzież district $(71.6 \%)$, Jarocin district $(72.8 \%)$, Wolsztyn district (66.1\%) and Szamotuly district (65.3\%). A slightly smaller part of the rural population were served by wastewater treatment plants in the following districts: Międzychód, Oborniki, Piła and Poznań. What should be emphasized is that an increase of this indicator (compared to 2005) was reported in all districts covered by this study (Table 1). More than four times growth was reported in the Oborniki district (by 48.95 percentage points) and Rawicz district (by 35.53 percentage points). Also, it tripled in the Kościan district (by 38.19 percentage points) and Leszno district (by 34.86 percentage points). Despite such favorable changes, wastewater management will remain at the core of measures taken to improve the condition of the voivodeship's aquatic environment under the National Program for Municipal Wastewater Treatment (Program..., 2012). This is because one of the key problems of rural areas continues to be the disproportion between water supply from networks and the controlled discharge and treatment of wastewater.
Municipal waste is an important aspect for the assessment of sustainable development in the context of environmental governance. Each year, more and more mixed waste is generated. This is a negative yet unavoidable development caused by intensified consumerism. In 2015, in the Wielkopolskie voivodeship, 873 tons of waste were collected (a share of $10.5 \%$ in the volume of waste collected on a countrywide basis). Over one third of that volume was generated in rural areas (which is above the countrywide average level for rural areas), and the growth rate reached nearly $200 \%$ over the years covered by this study. However, the percapita ratio was slightly more favorable. In 2005, the volume of mixed waste collected in rural areas of the Wielkopolskie voivodeship was $111.8 \mathrm{~kg}$ per capita. In 2015, it reached $195.4 \mathrm{~kg}$ per capita (Table 1). Note that the spatial distribution of per-capita waste volumes in the first year covered by the analysis was highly uneven (from $32.1 \mathrm{~kg}$ in the Ostrzeszów district to $226.4 \mathrm{~kg}$ in the Poznań district), whereas recently the disproportions between districts have considerably decreased (from $114.3 \mathrm{~kg}$ in the Kalisz district to $290.4 \mathrm{~kg}$ in the Poznan district).

The larger is the volume of waste generated, the higher is the pressure on the environment. Therefore, one of the strategic objectives behind the sustainable development concept is to reduce waste generation by promoting appropriate consumption patterns and raising the society's environmental awareness (Wskaźniki..., 2011). As shown by the results, these objectives were achieved to the smallest extent in the following districts: Chodzież, Krotoszyn, Ostrzeszów, Rawicz and Śrem, where the per-capita volume of mixed waste increased several times (Table 1). In absolute terms, the highest increase was reported in the Chodzież district (by $164.58 \mathrm{~kg}$ ), Rawicz district (164.14 kg) and Czarnków-Trzcianka district $(157.24 \mathrm{~kg})$.

The climate change issues and the necessary environmental protection measures are focused on energy consumption and sources. In 2015, the total per-capita low-voltage electricity consumption in Polish rural areas was $748.2 \mathrm{kWh}$, which means an increase by $12.3 \%$ $(82.1 \mathrm{kWh})$ compared to 2005 . In turn, as regards rural areas of the Wielkopolskie voivodeship, while the per-capita electricity consumption was higher $(770.5$ $\mathrm{kWh}$ ), it grew at a considerably slower rate of 5.9\% (by $42.61 \mathrm{kWh}$ ) (Table 1). As shown by the analysis, the above indicator was characterized by the most even 
Dolata, M., Jaworska, M. (2018). Differences in environmental governance levels in the sustainable development of rural areas of the Wielkopolskie voivodeship. J. Agribus. Rural Dev., 1(47), 21-28. http://dx.doi.org/10.17306/J.JARD.2018.00400

Table 1. Selected indicators of environmental governance in the sustainable development of rural areas; ranking of districts in Wielkopolskie voivodeship, compared to Poland and districts, in 2005 and 2015

\begin{tabular}{|c|c|c|c|c|c|c|c|c|c|c|c|c|c|c|c|c|c|}
\hline \multirow[t]{2}{*}{ Specification } & \multicolumn{3}{|c|}{ Forest cover } & \multicolumn{3}{|c|}{ Mixed waste collected } & \multicolumn{3}{|c|}{$\begin{array}{l}\text { Consumption } \\
\text { of water }\end{array}$} & \multicolumn{3}{|c|}{$\begin{array}{l}\text { Beneficiary } \\
\text { of sewage } \\
\text { treatment plants }\end{array}$} & \multicolumn{3}{|c|}{$\begin{array}{c}\text { Consumption electric } \\
\text { energy }\end{array}$} & \multicolumn{2}{|c|}{ Ranking } \\
\hline & 2005 & 015 & $\%$ & 2005 & 2015 & $\%$ & 2005 & 2015 & $\%$ & 2005 & 2015 & $\%$ & 2005 & 2015 & $\%$ & 2005 & 2015 \\
\hline Polska & 29.4 & 30.1 & 102.4 & 94.0 & 142.3 & 151.3 & 295.6 & 376.6 & 127.4 & 20.4 & 39.6 & 194.2 & 666.2 & 748.2 & 112.3 & - & - \\
\hline $\begin{array}{l}\text { Wielkop } \\
\text { voivode }\end{array}$ & 26.1 & 26.3 & 101.1 & 111.8 & 195.4 & 174.8 & 104.0 & 107.3 & .2 & 23.2 & 1.3 & 190.7 & 27.9 & 770.5 & 105.9 & - & - \\
\hline \multicolumn{18}{|l|}{ Districts: } \\
\hline chodzieski & 35.9 & 35.8 & 99.6 & 62.7 & 227.3 & 362.6 & 297.5 & 528.1 & 177.5 & 39.8 & 71.6 & 179.9 & 647.4 & 726.0 & 112.1 & 109 & 85 \\
\hline $\begin{array}{l}\text { czarnkowsko- } \\
\text {-trzcianecki }\end{array}$ & 51.3 & 51.8 & 100.9 & 73.1 & 230.3 & 315.2 & 111.8 & 239.3 & 214.0 & 20.5 & 34.8 & 169.7 & 717.7 & 769.5 & 107.2 & 95 & 9 \\
\hline gnieźnieński & 15.0 & 15.0 & 99.9 & 120.3 & 190.5 & 158.4 & 101.3 & 108.5 & 107.0 & 27.3 & 41.0 & 149.8 & 671.3 & 709.6 & 105.7 & 70 & 54 \\
\hline gostyński & 14.4 & 14.3 & 99.4 & 63.7 & 118.0 & 185.4 & 85.6 & 105.5 & 123.2 & 18.1 & 40.8 & 226.0 & 761.4 & 825.4 & 108.4 & 64 & 65 \\
\hline grodziski & 24.4 & 24.4 & 100.0 & 102.6 & 157.8 & 153.8 & 119.5 & 172.9 & 144.7 & 22.1 & 29.2 & 132.1 & 765.8 & 745.1 & 97.3 & 69 & 72 \\
\hline jarociński & 18.5 & 18.9 & 102.2 & 73.0 & 185.5 & 254.2 & 60.6 & 72.8 & 120.1 & 44.0 & 72.8 & 165.7 & 635.1 & 636.2 & 100.2 & 116 & 108 \\
\hline kaliski & 20.2 & 20.3 & 100.6 & 40.4 & 114.3 & 282.8 & 84.4 & 92.5 & 109.6 & 20.3 & 33.4 & 164.4 & 684.5 & 773.1 & 113.0 & 95 & 85 \\
\hline kępiński & 19.7 & 20.0 & 101.6 & 87.3 & 157.4 & 180.2 & 47.2 & 45.1 & 95.5 & 21.4 & 56.8 & 265.8 & 648.4 & 662.8 & 102.2 & 102 & 112 \\
\hline kolski & 11.4 & 12.0 & 104.9 & 131.4 & 152.3 & 115.9 & 58.1 & 46.0 & 79.2 & 13.7 & 21.8 & 159.6 & 896.1 & 659.7 & 73.6 & 46 & 86 \\
\hline koniński & 15.9 & 16.4 & 103.2 & 80.6 & 183.4 & 227.5 & 35.9 & 40.8 & 113.5 & 17.4 & 28.8 & 165.7 & 671.9 & 680.7 & 101.3 & 89 & 86 \\
\hline kościański & 13.8 & 13.8 & 100.3 & 100.7 & 153.7 & 152.6 & 76.7 & 89.3 & 116.3 & 18.6 & 56.8 & 305.2 & 750.2 & 785.4 & 104.7 & 62 & 6 \\
\hline krotoszyński & 19.0 & 19.1 & 100.4 & 33.0 & 165.0 & 500.1 & 100.5 & 89.0 & 88.5 & 11.6 & 21.6 & 186.0 & 808.5 & 786.4 & 97.3 & 63 & 58 \\
\hline leszczyński & 24.9 & 24.8 & 99.8 & 143.5 & 246.6 & 171.9 & 76.7 & 83.4 & 108.6 & 14.2 & 49.1 & 345.5 & 769.1 & 813.1 & 105.7 & 63 & 64 \\
\hline międzychodzki & 45.0 & 45.3 & 100.7 & 124.3 & 156.9 & 126.2 & 263.2 & 298.0 & 113.2 & 24.6 & 62.3 & 253.4 & 790.3 & 827.1 & 104.7 & 69 & 84 \\
\hline nowo & 38 & 38 & 5 & 1 & 9 & 28 & 13 & 4 & .5 & 10.2 & 4 & 250.3 & 724.9 & 795.6 & 109.7 & 78 & 2 \\
\hline obornicki & 31.5 & 31.7 & 100.6 & 59.8 & 185.9 & 310.7 & 87.4 & 135.1 & 154.5 & 13.6 & 62.5 & 461.1 & 719.4 & 770.0 & 107.0 & 86 & 89 \\
\hline ostrowski & 28.7 & 28.9 & 100.9 & 83.9 & 236.5 & 281.9 & 215.2 & 156.0 & 72.5 & 11.5 & 25.6 & 221.9 & 584.1 & 689.9 & 118.1 & 78 & 63 \\
\hline ostrzesz & 35.1 & 35.3 & 100.6 & 32.1 & 119.7 & 372.5 & 239.5 & 230.0 & 96.0 & 12.9 & 26.9 & 207.6 & 668.1 & 672.3 & 100.6 & 90 & 93 \\
\hline pilski & 26 & 27.1 & 10 & 0 & .7 & 106.7 & 138.6 & 19 & .3 & 39.7 & 63.2 & 159.0 & 663.0 & 735.4 & 110.9 & 85 & 8 \\
\hline pleszewski & 19.6 & 20.2 & 103.3 & 90.9 & 132.9 & 146.2 & 41.4 & 45.1 & 108.9 & 14.9 & 30.7 & 205.4 & 650.3 & 690.2 & 106.1 & 93 & 105 \\
\hline poznański & 22.5 & 22.8 & 101.0 & 226.4 & 290.4 & 128.3 & 66.1 & 70.3 & 106.4 & 38.2 & 60.7 & 158.8 & 878.5 & 952.6 & 108.4 & 72 & 65 \\
\hline rawicki & 153 & 15 & 99.6 & 43.8 & 208.0 & 474.6 & 85.1 & 78.4 & 2 & 10.3 & 45.9 & 443.6 & 805.5 & 803.2 & 00 & 57 & 58 \\
\hline słupecki & 15.2 & 15.4 & 101.5 & 160.3 & 180.2 & 112.4 & 47.8 & 60.0 & 125.7 & 33.3 & 39.8 & 119.2 & 675.9 & 680.6 & 100.7 & 83 & 89 \\
\hline szamotulski & 31.2 & 31.4 & 100.7 & 77.7 & 157.6 & 202.9 & 66.5 & 61.2 & 92.0 & 37.0 & 65.3 & 176.8 & 779.7 & 806.5 & 103.4 & 101 & 108 \\
\hline średzki & 16.8 & 16.7 & 99.8 & 159.0 & 197.9 & 124.5 & 68.8 & 65.7 & 95.5 & 32.8 & 57.2 & 174.2 & 767.3 & 825.2 & 107.5 & 70 & 72 \\
\hline śremski & 20.2 & 20.2 & 100.0 & 45.9 & 198.6 & 432.2 & 210.9 & 125.6 & 59.6 & 28.3 & 56.0 & 198.2 & 781.9 & 853.8 & 109.2 & 79 & 5 \\
\hline turecki & 25.0 & 25.4 & 101.7 & 57.8 & 154.5 & 267.3 & 84.1 & 76.2 & 90.7 & 16.0 & 20.3 & 126.9 & 567.2 & 637.2 & 112.3 & 105 & 95 \\
\hline wągrowiecki & 19.0 & 19.3 & 101.6 & 142.6 & 192.6 & 135.1 & 441.8 & 324.7 & 73.5 & 24.3 & 35.6 & 146.7 & 735.9 & 766.2 & 104.1 & 52 & 55 \\
\hline wolsztyński & 30.4 & 30.5 & 100.2 & 141.9 & 189.5 & 133.5 & 61.3 & 68.1 & 111.0 & 24.5 & 66.1 & 269.3 & 842.3 & 850.7 & 101.0 & 79 & 2 \\
\hline wrzesiński & 18.2 & 18.3 & 100.2 & 224.1 & 251.7 & 112.3 & 84.5 & 85.9 & 101.7 & 8.5 & 23.7 & 277.4 & 722.1 & 807.8 & 111.9 & 44 & 39 \\
\hline złotowski & 45.2 & 46.4 & 102.6 & 104.9 & 139.7 & 133.2 & 69.3 & 68.5 & 98.9 & 28.3 & 51.9 & 183.3 & 617.5 & 650.9 & 105.4 & 116 & 128 \\
\hline
\end{tabular}

Source: own elaboration based on Local Data Bank, n.d. 
spatial distribution among the selected components of environmental governance in the region covered by this study. The per-capita amount of energy consumed by the rural population spanned from $567.2 \mathrm{kWh}$ (Turek district) to $896.1 \mathrm{kWh}$ (Koło district) in 2005, and from $636.2 \mathrm{kWh}$ (Jarocin district) to $952.6 \mathrm{kWh}$ (Poznań district) in 2015. The highest increase in electricity consumption (beyond the average growth rate for rural areas in this voivodeship) was reported in the Ostrów district (by 18.1\%) and Kalisz district (by 13.0\%). Meanwhile, a reduction in electricity consumption was recorded in the following four districts: Koło (by 26.4\%), Grodzisk and Krotoszyn (by 2.7\%) and Rawicz (by $0.3 \%$ ) (Table 1). This trend is the consequence of the growing consumption of durables, and therefore it is important to take measures aimed at improved energy efficiency or changing the energy mix towards renewables. Wielkopolska is a region with favorable conditions for the development of renewable energies. Most of the local municipalities have the potential to use at least two renewable sources of energy (Program..., 2012). While this course of action becomes increasingly noticeable in the voivodeship, it is an opportunity and a challenge on the path towards modern, sustainable regional development (Wskaźniki..., 2017).
The values of selected indicators of the environmental aspect of sustainable development of rural areas were used as the basis to rank the districts. As shown by the analysis of the ranking, there was a relatively small change in the spatial differentiation of this aspect in the Wielkopolskie voivodeship between 2005 and 2015 (Fig. 1). In 2005, Jarocin and Złotów were the two top-ranked districts with a score of 116 . The first one demonstrated the highest share of users of wastewater treatment plants and a low per-capita consumption of water and energy. Due to increased amounts of waste and water consumption, in 2015, that district dropped to the third rank (108 points). Note that it was the only territorial unit under consideration to receive the highest score for two parameters at the same time. In turn, the Złotów district was the leader because of high forest cover ratios and reasonable energy management, which earn it a high score (of 29 and 30, respectively) after 10 years, too. Also, due to improved water and sewerage management, in 2015, it became the undisputable leader of sustainable rural development in the Wielkopolskie voivodeship as regards environmental governance, with a total score of 128. In addition to Złotów and Jarocin districts, the top five also included Kępno (112 points), Szamotuły (108 points) and Pleszew (105 points)
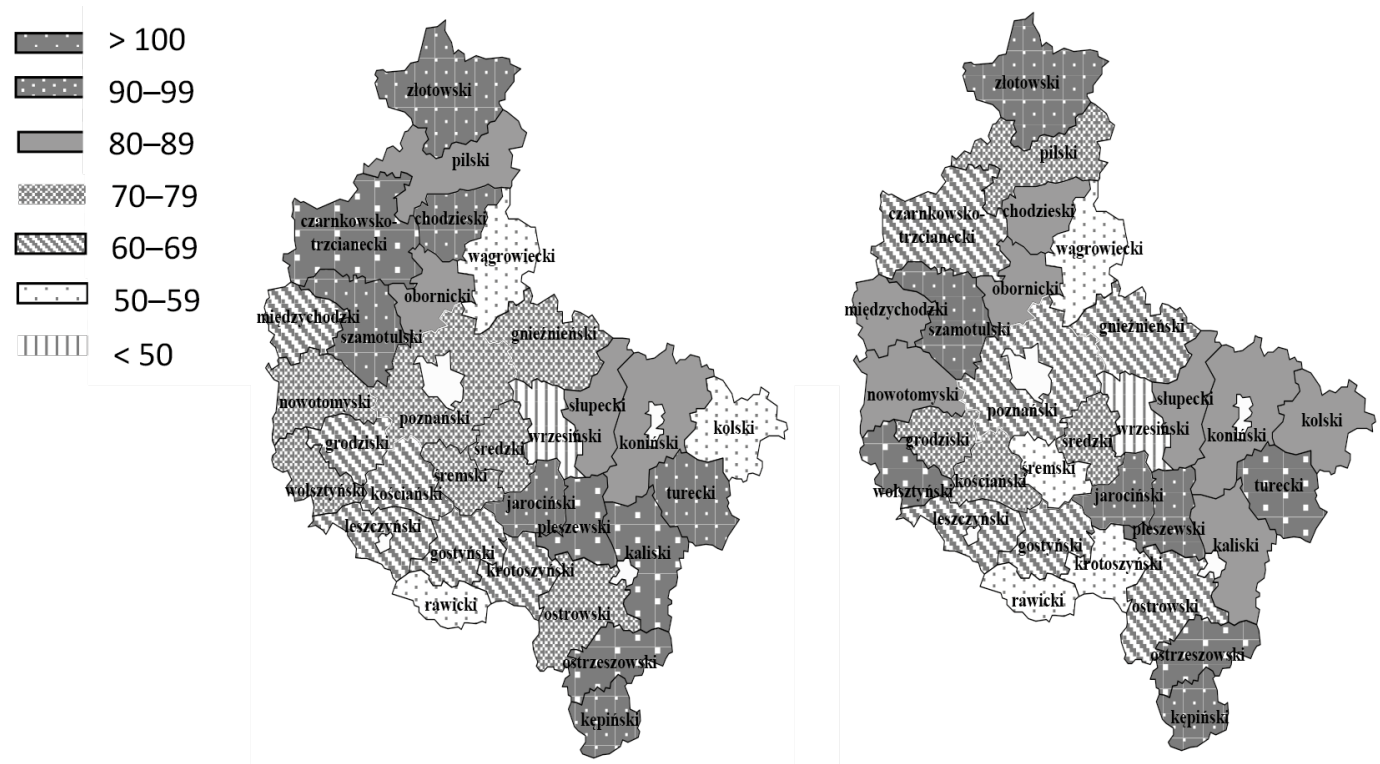

Fig. 1. Delimitation of rural areas of the Wielkopolskie voivodeship by level of environmental governance in the sustainable development of districts in 2005 and 2015 
districts. The analysis of scores earned in specific areas clearly identified the ones that need to be improved. In Kępno and Jarocin districts, measures would need to be taken to implement sustainable forest management and increase the forest cover ratio. In turn, the Szamotuly district should make a shift towards efficient energy management while the Pleszew district should focus on wastewater management. As shown by the comparison of the top five districts, in 2015, the situation particularly deteriorated in the Chodzież district (a decline by 24 points), ultimately ranked $13^{\text {th }}$. With a relatively very high share of the population served by sewage treatment plants and the highest water consumption ratio, adverse changes affected its waste and energy management processes. Territorial units where a similar decrease in the score was experienced include the Czarnków-Trzcianka district (by 26 points) and Śrem district (by 24 points). In the analysis, attention should be paid to the Września district, ranked at the bottom with a score of only 44 in 2005 and 39 in 2015 (Fig. 1). What also should be emphasized is that many districts demonstrated an improvement of sustainability levels of their rural areas, as determined based on selected environmental governance indicators. The most considerable improvements were reported in the following districts: Koło (by 40 points), Międzychód (by 15 points), Kościan (by 14 points) and Wolsztyn (by 13 points).

\section{SUMMARY}

The following conclusions may be drawn from the analysis of environmental governance levels in the sustainable development of rural areas of districts of the Wielkopolskie voivodeship.

1. In 2015, the forest cover ratio in the Wielkopolskie voivodeship was below the level recorded in rural areas on a countrywide basis. The largest share of forests in rural areas was reported in the following districts: Czarnków-Trzcianka, Złotów and Międzychód. As shown by the evolution of that indicator, while the developments are positive and consistent with the expectations, the pace of changes was relatively slow.

2. The Wielkopolskie voivodeship recorded one of the country's highest levels of per-capita water consumption (which decreased over the period covered by this analysis). The opposite trend was observed in rural areas where the per-capita consumption of aquatic resources was three times lower than the country's overall level. The highest consumption was reported in the following districts: Chodziez, Wągrowiec and Międzychód. As shown by the spatial dispersion analysis, this indicator strongly varies across regions.

3. In the period under consideration, the number of rural users of wastewater treatment plants more than doubled. The spatial distribution of that indicator across the Wielkopolskie voivodeship was relatively even. In 2015, the highest share was reported in the following districts: Chodzież, Jarocin, Wolsztyn and Szamotuły.

4. A negative yet unavoidable development was the gradual increase of the amount of mixed waste over the years. Over one third of waste collected in the Wielkopolskie voivodeship was generated in rural areas, and the growth rate reached nearly $200 \%$ over the years covered by this study. The highest increase of the per-capita ratio was observed in the following districts: Chodzież, Krotoszyn, Ostrzeszów, Rawicz and Śrem. In the first year under consideration, the spatial distribution of that indicator was highly uneven, whereas during the second year, the disproportions between districts considerably decreased.

5. In rural areas of the Wielkopolskie voivodeship, the total per-capita consumption of electric energy was slightly above the country's overall figures. However, in these areas, the growth rate of energy consumption was definitely below the country's average level. As shown by the analysis, the above indicator was characterized by the most even spatial distribution among the selected components of environmental governance in the region covered by this study.

6. As shown by the ranking, there is quite considerable spatial differentiation of specific parameters covered by this study; however, when analyzed globally, environmental governance proves to be a relatively non-diversified process. In 2015, as regards the level of environmental governance in rural areas, the highest scores were obtained by the following districts: Złotów, Kępno and Jarocin. In turn, the lowest scores were found in Września, Wągrowiec and Śrem districts. The summary approach presented in the ranking allowed to identify several territorial units with the best performance in improving the condition of environmental governance. These include the following districts: Koło, Międzychód and Kościan. 
Meanwhile, worrying changes could be observed in three districts: Czarnków-Trzcianka, Jarocin and Śrem.

Finally, it is to be noted that this paper presents only the scope and nature of differences between specific rural areas of the Wielkopolskie voivodeship as regards selected environmental governance components. The results of this study are only a starting point for further research. Also, the results do not clearly set a direction for implementation of the sustainable development concept. For that purpose, this study would need to be extended with other indicators for specific thematic areas.

\section{REFERENCES}

Adamowicz, M. (2000). Rola polityki agrarnej w zrównoważonym rozwoju obszarów wiejskich [The importance of agrarian policy in sustainable development of rural areas]. Rocz. Nauk. SERiA, 2(1), 69 [in Polish].

Bank Danych Lokalnych GUS [Local Data Bank Central Statistical Office of Poland] (n.d.). Retrieved Aug 25 2017 [in Polish].

Borys, T. (2005). Wskaźniki zrównoważonego rozwoju [Sustainable Development Indicators]. Białystok: Wyd. Ekonomia i Środowisko [in Polish].

Borys, T., Fiedor, B. (2008). Operacjonalizacja i pomiar kategorii zrównoważonego rozwoju - przyczynek do dyskusji [Operationalization and measurement of sustainable development - a contribution to the discussion]. In: M. Plich (Ed.), Rachunki narodowe. Wybrane problemy i przykłady zastosowań (p. 115-131) [in Polish].

Dolata, M. (2015). Znaczenie infrastruktury w koncepcji trwałego i zrównoważonego rozwoju obszarów wiejskich [Importance of Sustainable Infrastructure In Concept of Sustainable Development of Rural Areas]. Zesz. Nauk. Uniw. Szczec., 40(2), 45-46 [in Polish].

Hadryjańska, B. (2015). Ekologizacja procesu produkcji a kształtowanie konkurencyjności w przedsiębiorstwach przetwórstwa mleczarskiego [Ecologizing the production process and shaping competitiveness in dairy enterprises]. Poznań: PTE, Oddział w Poznaniu [in Polish].

Kierunki rozwoju obszarów wiejskich. Założenia do „Strategii zrównoważonego rozwoju wsi i rolnictwa" [Directions of rural development. Assumptions for „Sustainable Development Strategy of Rural Areas and Agriculture"] (2010). Warszawa: Ministerstwo Rolnictwa i Rozwoju Wsi [in Polish].

Leśniewski, M. A. (2010). Zrównoważony rozwój a konkurencyjność gmin [Sustainable development and competitiveness of municipalities]. Kielce: Wyd. Uniwersytetu Humanistyczno-Przyrodniczego Jana Kochanowskiego [in Polish].

Program ochrony środowiska województwa wielkopolskiego na lata 2012-2015 [Environmental protection program for the Wielkopolskie Voivodeship 2012-2015] (2012). Poznań [in Polish].

Roszkowska-Mądra, B. (2009). Koncepcje rozwoju europejskiego rolnictwa i obszarów wiejskich [The concepts of agricultural and rural development in the European Union]. Gosp. Narod., 10, 84 [in Polish].

Stanny, M. (2013). Przestrzenne zróżnicowanie rozwoju obszarów wiejskich w Polsce [Spatial diversification of rural area development in Poland]. Warszawa: Wyd. IRWiR PAN [in Polish].

Stanny, M., Czarnecki, A. (2011). Zrównoważony rozwój obszarów wiejskich Zielonych Płuc Polski. Próba analizy empirycznej [Sustainable development of rural areas of the Green Lungs of Poland region An attempt at empirical analysis]. Warszawa: Wyd. IRWiR PAN [in Polish].

Sustainable development in the European Union. 2015 monitoring report of the EU Sustainable Development Strategy (2015). EUROSTAT Statistical books. Luxembourg.

Wskaźniki zielonej gospodarki w Polsce 2017 [Green economy indicators in Poland 2017] (2017). Białystok: GUS, Urząd Statystyczny w Białymstoku [in Polish].

Wskaźniki zrównoważonego rozwoju Polski [Sustainable Development Indicators of Poland] (2011). Katowice: GUS, Urząd Statystyczny w Katowicach [in Polish].

Wskaźniki zrównoważonego rozwoju Polski [Sustainable Development Indicators of Poland] (2015). Katowice: GUS, Urząd Statystyczny w Katowicach [in Polish].

Żylicz, T. (2004). Ekonomia środowiska i zasobów naturalnych [Economics of the environment and natural resources]. Warszawa: PWE [in Polish]. 